\title{
Sosialisasi Pengembangan Ekspor Melalui International E-Commerce di Kampung Batik Laweyan Solo
}

\section{Oleh :}

Dra. Christy Damayanti, M.Si; Unisri; Surakarta; email : christydhartono@gmail.com

Andika Drajat Murdani, S.IP., M.A.; Unisri; Surakarta; email : andika.drajat.m@gmail.com

\begin{abstract}
ABSTRAK
The e-commerce market trend is taking place around the world. This trend encourages international trade be more intense. This can be an opportunity for Indonesia to be able to develop its exports rate using e-commerce. Based on this background, this program purposes to provide indeep information to industry and trade players about how to increase their potential and expand the market through international e-commerce. This international e-commerce should be a solution to improve its economic welfare. The method of this program is carried out through assessment and socialization at the location of service, as Kampung Batik Laweyan Solo. Exploration activities were to obtain detailed information about program targets, which are held in August and September 2018. Furthermore, a one-day socialization event is held on 28 October 2018. The results of this program are (1) business actors can obtain information about the potential export by utilizing international e-commerce; (2) for the region, can develop regional potential, regional promotion, and regional economic development; (3) for universities, as a fulfillment of the Tri Dharma elements of Higher Education.
\end{abstract}

Keywords : export, international e-commerce, Kampung Batik Laweyan

\section{PENDAHULUAN}

\section{A. Latar Belakang}

Tidak bisa dipungkiri bahwa teknologi yang berkembang mampu memunculkan pola baru dalam hubungan internasional, termasuk dalam hal perdagangan internasional. Teknologi telah berhasil menciptakan konsep global e-commerce dan online retail sebagai cara baru dalam bertransaksi. Transaksi e-commerce bisa dilakukan dengan cara yang sangat fleksibel sehingga cara berjualan ini banyak dipilih dan berkembang pesat di seluruh dunia. Tren e-commerce bahkan diprediksi akan terus meningkat secara dramatis dan belum ada tanda- tanda adanya tren penurunan (Cohen, 2017).

Pesatnya perkembangan e-commerce dibuktikan dari data statista menunjukkan nilai penjualan lewat retail e-commerce di seluruh dunia yang mencapai nilai sekitar 1,86 trillion US dollars, dan diprediksi akan meningkat hingga 4,48 trillion US dollars pada tahun 2021. Bahkan, data menunjukkan bahwa aktivitas online masyarakat dunia yang paling banyak dilakukan adalah aktivitas online shopping (statista, 2018). 
Dari data tersebut, dapat disimpulkan bahwa e-commerce ini tengah menjadi tren dalam hubungan internasional di ranah perdagangan. Tren pasar e-commerce yang berlangsung di seluruh dunia ini bahkan juga mendorong terjadinya perdagangan internasional yang lebih intens. Sebab, 65\% konsumen cenderung lebih suka melakukan pembelian dari pasar global (luar negeri) daripada membeli di pasar lokal (Cohen, 2017).

Hal ini merupakan peluang tersendiri bagi Indonesia untuk dapat mengembangkan ekspor dengan memanfaatkan e-commerce. Untuk menangkap peluang ini, kita perlu mengkolaborasikan pasar dunia yang terbuka lebar dengan teknologi yang mendorong perkembangan e-commerce, serta potensi yang dimiliki oleh kota Solo. Kota Solo dipilih karena berada satu wilayah dengan PT peneliti.

Selain itu, Kota Solo yang memiliki luas wilayah $44,04 \mathrm{~km}^{2}$ ini populer sebagai pusat perdagangan dan pusat budaya. Ekonomi dan perdagangan di kota Solo memang sangat terasa. Dari segi perdagangan internasional pun, Solo juga memiliki peran yang cukup berarti. Hal ini dilihat dari peran kota Solo sebagai salah satu fasilitator perdagangan luar negeri atau kegiatan eskpor dengan adanya Departemen Luar Negeri di bawah Dinas Perindustrian dan Perdagangan Kota Surakarta. Di provinsi Jawa Tengah hanya terdapat tiga wilayah yang dapat mengurusi kegiatan ekspor, yakni Cilacap, Semarang, dan Solo.

Kondisi ini menjadikan potensi Solo untuk masuk ke ranah ekspor juga semakin terbuka lebar. E-commerce dapat menjadi bentuk keterlibatan dalam diplomasi ekonomi kota Solo. Pengembangan ekspor kota Solo perlu dilakukan dalam rangka pengembangan ekonomi masyarakatnya. Jika merujuk pada data statistik ekspor Jawa Tengah, terdapat peningkatan ekspor dari tahun ke tahun. Pada tahun 2010, nilai ekspor Jawa Tengah mencapai 3.868,9 juta US\$ (Statistik Ekspor Jawa Tengah Tahun 2011). Dan di tahun 2016 meningkat menjadi 5.389,2 juta US\$. Nilai ekspor ini didominasi oleh produk non-migas (Statistik Ekspor Jawa Tengah tahun 2016).

Dari data tersebut, dapat diketahui bahwa selama enam tahun, terdapat peningkatan hingga 43,6 \%. Peningkatan ekspor ini menunjukkan bahwa sudah ada potensi besar yang bisa dikembangkan oleh wilayah Jawa Tengah, termasuk kota Solo untuk memasuki pasar ekspor. Hal ini bisa berpotensi lebih meningkatkan lagi bila peran UMKM dalam kegiatan ekspor juga semakin meningkat. Ekonomi kota Solo sendiri juga banyak didorong dari aktivitas UMKM (Widiastuti, 2017).

Program pengabdian pada masyarakat ini berusaha untuk meningkatkan kegiatan ekspor yang ada di Solo dengan memanfaatkan e-commerce. Apalagi, di tingkat global, penelitian Bank Dunia menunjukkan bahwa keterlibatan UMKM secara digital menjadi 
mampu mendorong pencapaian target pertumbuhan ekonomi sebesar 7\% pada tahun 2025 mendatang (Sidik, 2017).

Karenanya, diharapkan melalui kolaborasi antara UMKM dengan e-commerce yang ada di Solo, nilai ekspor kota Solo bisa terus meningkat. Era revolusi digital harus bisa dimanfaatkan agar bisa memaksimalkan potensi ekspor di kota Solo. Faktanya masih banyak UMKM yang belum memaksimalkan kesempatan ini. UMKM banyak yang belum menguasai teknologi untuk memanfaatkan e-commerce sebagai pendorong ekspor produknya.

Untuk memfokuskan wilayah pengabdian yang diimplementasikan, pelaksana memilih untuk mempersempit wilayah pengabdian ke daerah yang banyak terdapat UMKM. Pilihan pengabdian yang ditentukan adalah di wilayah Kampung Batik Laweyan yang merupakan sentra industri batik. Di Kampung Batik Laweyan, mayoritas masyarakatnya bergerak sebagai UMKM terutama yang terkait dengan usaha batik. Dapat dikatakan, penopang ekonomi utama dari wilayah ini adalah dari sektor industri batiknya. Untuk itu, dirasa tepat untuk melaksanakan program pengabdian masyarakat dengan tema “pengembangan ekspor melalui internetional e-commerce” di Laweyan mengingat banyaknya potensi yang dapat dimaksimalkan di wilayah tersebut.

\section{B. Rumusan Masalah}

Berdasarkan pada uraian di atas maka rumusan masalah yang hendak dijawab melalui kegiatan Pengabdian pada Masyarakat ini adalah sebagai berikut: "Bagaimana pengembangan ekspor melalui international e-commerce di kota Solo?”

\section{Tujuan dan Manfaat}

Pelaksanaan Pengabdian Pada Masyarakat ini memiliki target-terget tertentu sebagai tujuan yang ingin dicapai. Adapun tujuan yang hendak dicapai melalui program ini, sebagai berikut:

1. Dapat menumbuhkan minat dan memberikan gambaran bagi para pelaku usaha mengenai upaya pengembangan ekspor melalui international e-commerce, seabgai jalan meningkatkan kesejahteraan ekonomi masyarakat.

2. Dapat meningkatkan komunikasi dengan para pelaku industri dan perdagangan dalam bentuk sosialsiasi sebagai proses awal untuk lebih memahami tentang kondisi masyarakat dalam kegiatan ekonominya, terutama dalam hal kegiatan ekspor.

3. Dapat memberikan bekal wawasan kepada para pelaku industri dan perdagangan tentang bagaimana meningkatkan potensi dan memperluas pasar melalui international $e$ commerce sebagai solusi untuk meningkatkan kesejahteraan ekonominya.

Pengabdian pada masyarakat ini diharapkan dapat memberikan manfaat bagi: 
1. Para pelaku industri dan perdagangan sebagai peserta yang merupakan aktor ekonomi, sekaligus dapat menjadi aktor hubungan internasional, sehingga dapat memperoleh pemahaman dan wawasan akan pentingnya meningkatkan kompetensi dan mengembangkan usahanya melalui international e-commerce. Perkembangan usaha diperlukan karena dapat berpengaruh terhadap peningkatan kesejahteraannya sendiri, sekaligus mampu berkontribusi terhadap peningkatan ekonomi negara.

2. Wilayah kota Solo, dengan adanya sosialisasi tentang potensi ekspor melalui international e-commerce, diharapkan bisa menjadi sarana bagi pengembangan wilayah serta meningkatkan nilai ekspor di kota Solo, sehingga dapat pula mendorong peningkatan ekonomi yang lebih luas melalui rembesan -rembesan ekonomi yang terjadi, sekaligus menyerap tenaga kerja lebih luas lagi.

3. Perguruan tinggi, melalui kegiatan pengabdian pada masyarakat ini menjadi salah satu elemen penting guna memenuhi Tri Dharma Perguruan Tinggi yang hasilnya dapat memberikan masukan bagi perkembangan Unit LP2M dan sebagai pendukung kegiatan Tri Dharma Perguruan Tinggi selain pendidikan pengajaran dan penelitian.

\section{BAB II METODE PELAKSANAAN}

Pelaksanaan program pengabdian kepada masyarakat ini dilaksanakan dengan target peserta yakni para pelaku industri dan perdagangan yang berasal dari Kota Solo. Adapun pelaku usaha ini difokuskan pada peserta yang berada di kawasan kampung batik Laweyan Solo. Kampung Batik Laweyan Solo dianggap sesuai dengan program pengabdian karena para pelaku usaha ini juga memiliki kebutuhan akan perluasan ekspor melalui pemanfaatan international e-commerce.

\section{A. Realisasi Pelaksanaan}

Tahap persiapan program pengabdian pada masyarakat dilakukan dengan penjajagan yang lebih mendalam mengenai kondisi lingkungan tempat program akan dilaksanakan. Dalam hal ini, penjajagan dilakukan di Kampung Batik Laweyan Solo, dengan perantara dari Forum Pengembangan Kampoeng Batik Laweyan, yang diketuai oleh Bapak Alpha Fabela Priyatmono.

Penjajagan dimaksudkan untuk mengetahui permasalahan apa saja yang dihadapi oleh para pelaku usaha di lokasi pengabdian secara lebih mendetail, terutama yang terkait dengan tema pegembangan ekspor melalui international e-commerce. Dengan demikian, materi yang disajikan pada para peserta nantinya dapat sesuai dengan kebutuhan dan dapat pula menjadi solusi bagi permasalahan mereka. Adapun implementasinya dilakukan mulai bulan Agustus hingga September 2018. 
Adapun jadwal realisasi pelaksanaan sosialisasi program pengabdian masyarakat :

Hari : Minggu

Tanggal : 28 Oktober 2018

Jam $\quad: 12.30-15.00$

Tempat $\quad$ : Ndalem Njimatan Setono, Laweyan Surakarta.

Jumlah peserta $\quad$ : orang

Pemaparan materi dilakukan dengan menyesuaikan pada kebutuhan dan kondisi pelaku usaha di lokasi pengabdian. Pemaparan bertujuan untuk memberi gambaran bagi para pelaku usaha akan pentingnya pengembangan pasar ekspor dan potensinya, sekaligus diharapkan dapat memberi motivasi bagi para pelaku usaha agar memiliki target untuk mengembangkan usahanya memasuki pasar ekspor lewat sarana e-commerce.

\section{B. Kelompok Sasaran}

Kelompok sasaran dalam program pengabdian masyarakat ini adalah para pengusaha yang mendiami wilayah Kampung Batik Laweyan. Adapun kampung batik ini berada di wilayah Kota Surakarta, Jawa Tengah, yang selama ini populer sebagai kampung yang di dalamnya banyak terdapat produsen batik. Karena aktivitas masyarakatnya yang mayoritas membatik inilah, kampung ini lantas mendapat sebutan Kampung Batik Laweyan.

Dari pengamatan yang dilakukan, masyarakat di kampung batik Laweyan ini masih banyak yang bermata pencaharian sebagai pembatik, terutama sebagai produsen batik tradisional yang dibuat melalui proses tulis maupun cap. Rumah-rumah warganya banyak yang dijadikan sebagai showroom untuk menampilkan hasil produk batik buatan mereka sendiri, dan ada pula yang memproduksi batik untuk dititipkan pada toko-toko batik lain. artinya, sudah ada kerja sama yang terjalin antar pengusahanya.

Namun, perkembangan satu pengusaha dengan pengusaha lain juga terdapat perbedaan. Ada para pengusaha batik yang telah maju dan melakukan ekspor hingga ke manca negara. Di sisi lain, masih ada yang kesulitan mengembangkan usahanya. Alasan paling umum yang dihadapi adalah akses untuk melakukan ekspor yang terbatas serta keterbatasan modal pula.

Padahal, akses ekspor ini dapat terbuka dengan lebih mudah dan murah, bila para pengusahanya mampu memanfaatkan international e-commerce dengan baik. Masalah lain, penguasaan masyarakat akan teknologi digital untuk e-commerce ini masih minim dan kebanyakan juga masih ragu akan potensi e-commerce ini. Karakter dan permasalahan yang dihadapi oleh masyarakat Kampung Batik Laweyan ini cocok dengan tema program pengabdian kepada masyarakat yakni terkait pengembangan ekspor melalui international ecommerce. 


\section{Metode yang diterapkan}

Pelaksanaan program pengabdian pada masyarakat dengan tema pengembangan ekspor melalui international e-commerce ini direalisasikan melalui kegiatan sosialisasi yang berlangsung selama satu hari, yakni pada hari Minggu, tanggal 28 Oktober 2018. Metode yang diterapkan dalam sosialisasi tersebut adalah dengan ceramah dan diskusi aktif.

Sosialisasi yang dilakukan bertujuan guna memperluas wawasan para pelaku industri dan perdagangan yang ada di lokasi pengabdian, utamanya agar memiliki orientasi ekspor. Kelompok sasaran diberikan gambaran secara jelas mengenai adanya potensi bagi mereka untuk dapat mengembangkan ekspor dengan memanfaatkan international e-commerce. Kelompok sasaran juga diberikan motivasi agar berminat dan berani melangkah menuju pasar ekspor. Sebab, untuk dapat memasuki pasar ekspor, banyak dari mereka yang merasa belum siap. Ketidaksiapan ini banyak dipengaruhi rasa tidak yakin akan potensinya dan belum memiliki informasi cukup tentang pasar ekspor, serta bagaimana cara melakukan ekspor.

Padahal, di era perkembangan digital seperti sekarang ini, kesempatan untuk memasuki pasar ekspor semakin terbuka lebar. Oleh karena itulah, pemberian pemahaman serta motivasi menjadi salah satu langkah penting dalam program pengabdian pada masyarakat ini. Selanjutnya, ceramah dilanjutkan dengan paparan mengenai bagaimana langkah praktis untuk mengembangkan ekspornya, terutama dengan cara yang murah dan mudah. Solusi yang ditawarkan adalah dengan memanfaatkan teknologi digital yang saat ini telah berkembang pesat. Kelompok sasaran diberikan gambaran mengenai peluang mereka dalam memanfaatkan international e-commerce untuk dapat masuk ke pasar ekspor.

Selanjutnya, kelompok sasaran diberikan kesempatan bertanya jawab dalam sesi diskusi aktif. Dalam metode ini, diskusi memungkinkan peserta memperoleh materi yang lebih dalam sesuai yang dibutuhkan serta untuk memberikan solusi terhadap permasalahan yang dihadapi. Kelompok sasaran dalam hal ini dapat langsung memberikan feed back terkait materi dan program. Materi-materi yang belum lengkap dan belum jelas disampaikan juga dapat dipertegas serta diperdalam lagi lewat sesi diskusi aktif. Sesi ini juga memungkinkan pelaksana pengabdian menemukan permasalahan baru yang mungkin dihadapi kelompok sasaran guna peningkatan program pengabdian selanjutnya.

\section{BAB III HASIL DAN PEMBAHASAN}

\section{A. Deskripsi Hasil}

Program pengabdian kepada masyarakat dengan tema pengembangan ekspor melalui international e-commerce diharapkan mampu memberikan hasil yang positif sesuai harapan. Pada 
tahap penjajagan, pelaksana program pengabdian mengumpulkan beberapa informasi seputar kondisi kelompok sasaran yakni Kampung Batik Laweyan, serta mengenai permasalahan-permasalahan terkait yang banyak dihadapi oleh kelompok sasaran.

Adapun kondisi Kampung Batik Laweyan menunjukkan bahwa di wilayah tersebut telah ada beberapa pelaku usaha yang melakukan ekspor. Hanya saja, jumlah pelaku usaha yang telah ekspor masih sedikit. Dituturkan oleh Ketua Forum Pengembangan Kampoeng Batik Laweyan, kebanyakan pengrajin batik menjual dagangannya di rumah saja dan menunggu para pembeli datang atau dengan menitipkan di toko-toko batik lain.

Namun, beberapa memang sudah ada yang melakukan ekspor. Hanya saja, prosedur ekspor yang digunakan mayoritas adalah melalui jalur konvensional, seperti pameran atau pencarian buyer secara langsung. Beberapa ada buyer asing yang telah berkunjung langsung ke Laweyan, mencari produk, lalu memesan kembali secara berkelanjutan untuk dilakukan ekspor ke negaranya. Dalam hal ini, para eksportir dituntut untuk aktif melakukan lobi terhadap buyer bahkan jika perlu mengunjungi negara buyer untuk melakukan penjajagan pasar.

Konsep perluasan pasar seperti ini cukup sulit diduplikasi oleh setiap pengusaha batik di Laweyan karena kebutuhan biaya yang tinggi. Padahal, masalah pendanaan atau permodalan merupakan masalah umum yang banyak dihadapi para pengusaha batik Laweyan. Untuk itu, dibutuhkan langkah perluasan pasar yang lebih mudah dengan biaya lebih murah. Salah satu solusi tepat di era perkembangan teknologi digital ini adalah dengan memanfaatkan e-commerce. Sayangnya, pemanfaatan e-commerce di Kampung Batik Laweyan sendiri masih tergolong minim. Jika pun ada, tatarannya baru skala nasional.

Informasi yang diperoleh menunjukkan bahwa Kampung Batik Laweyan telah mencoba melakukan pemasaran melalui e-commerce, akan tetapi masih sebatas nasional. Selain memanfaatkan beberapa marketplace, mereka membuat website bernama tokobatikbatik.com. Langkah ini cukup menguntungkan, meski tidak dapat memberikan hasil siginfikan. Selain itu, langkah ini juga tidak bisa menjangkau pasar ekspor.

Setelah mendapatkan gambaran mengenai kondisi dan permasalahan di Kampung Batik Laweyan terkait tema, tim pengabdian segera melakukan penyusunan materi. Adapun materi yang disajikan bagi kelompok sasaran tersebut berupa gambaran mengenai pesatnya perkembangan pasar e-commerce di dunia yang didukung dengan sajian data untuk menunjukkan peningkatan aktivitas perdagangan dunia.

Data menunjukkan bahwa setidaknya 53\% dari pengguna internet di seluruh dunia pernah melakukan pembelian secara online, dan 65\% konsumen yang melakukan pembelian secara online cenderung lebih suka melakukan pembelian dari pasar global (luar negeri) daripada membeli di pasar lokal. Hal inilah yang menunjukkan adanya potensi untuk melakukan ekspor dengan target pasar secara global, dengan memanfaatkan $e$-commerce. 
Selanjutnya, kelompok sasaran juga dikenalkan pada e-commerce. Dijelaskan bahwa pengertian e-commerce menurut Lindsay P., (2002) adalah proses membeli dan menjual barang dan jasa lewat internet, serta untuk mendapatkan informasi, membandingkan harga serta penawaran barang tertentu, yang kemudian bisa dijadikan bahan pertimbangan untuk bertransaksi secara tradisional (Khan, 2016 : 19).

Dengan memanfaatkan e-commerce untuk mengembangkan usaha, dapat diperoleh beberapa manfaat, seperti (1) Dapat meningkatkan market exposure (pangsa pasar); (2) Dapat menurunkan operating cost (biaya operasional); (3) Dapat melebarkan global reach (jangkauan global); (4) Dapat meningkatkan customer loyalty (kesetiaan pelanggan); (5) Dapat menigkatkan supply management (managemen penyediaan barang).

Adapun cara-cara yang dapat ditempuh untuk memanfaatkan $e$-commerce sebagai langkah pembukaan pasar ekspor adalah : (1) pembuatan website pribadi untuk company profile; (2) Menggunakan media sosial dengan target sasaran internasional/ negara tujuan tertentu; serta (3) Bergabung dengan marketplace internasional : Alibaba/ B2b/ Bizbive/ Etline/ Thaibynature.

Dalam realisasinya, ada beberapa strategi praktis yang dapat dilakukan, yakni dengan (1) menyajikan keterangan produk secara detail, mulai dari material, warna, fungsi, kapasitas produksi, dan hal lain yang dibutuhkan untuk mendeskripsikan produk; (2) menampilkan gambar yang menarik dan real picture; (3) Menggunakan bahasa Inggris yang sederhana dan mudah dipahami; (4) Sering update agar terlihat aktivitasnya; (5) membangun reputasi sebaik mungkin.

\section{B. Pembahasan}

Dari deskripsi hasil yang telah disampaikan, diketahui bahwa sesungguhnya kelompok sasaran telah mulai memanfaatkan e-commerce sebagai sarana penjualan. Akan tetapi, pemanfaatan ini masih belum maksimal karena hanya untuk penjualan skala nasional dan tanpa promosi masif. Hasil diskusi pada sesi sosialisasi juga menunjukkan bahwa para pelaku usaha ini masih belum memahami tata cara untuk penggunaan e-commerce untuk melakukan ekspor.

Kelompok sasaran banyak yang masih meragukan potensi e-commerce. Keraguan cenderung disebabkan minimnya informasi yang diterima terkait e-commerce. Padahal, setelah pemaparan, banyak yang kemudian merasa mendapat bekal dan gambaran cukup terkait pemanfaatan international e-commerce dan menyatakan siap mencoba melakukan ekspor melalui e-commerce. Ini menunjukkan bahwa bagi para pelaku usaha, penting bagi mereka untuk memahami peluang yang mereka miliki, terutama mengenai media yang bisa 
dimanfaatkan sebagai sarana memudahkan jalur ekspor dan membuka pasar baru di luar negeri.

Pemanfaatan teknologi digital sekaligus dapat dimanfaatkan secara maksimal untuk mengembangkan produk mereka dengan cara menyesuaikan produk yang ditawarkan dengan kebutuhan serta selera para calon konsumen. Sebab, teknologi digital tidak hanya dapat menjadi sarana penjualan, tapi juga sebagai sarana untuk memahami pasar sasaran. Lalu, sebagai langkah praktisnya, para pelaku usaha diminta bisa saling bekerja sama satu sama lain dalam pengembangan pasar ekspor melalui international e-commerce ini. Dalam artian, mereka dapat mengerahkan tenaga khusus atau profesional yang lebih memahami langkah praktis pemasaran melalui marketplace digital sembari belajar secara bertahap.

Selain itu, diharapkan adanya tindakan promosi secara tepat untuk lebih mempopulerkan produk mereka di pasar internasional. Promosi ini juga dapat dilakukan dengan memanfaatkan teknologi digital, seperti lewat media sosial atau marketplace itu sendiri. Dengan pelaksanaan promosi digital yang tepat, popularitas dan penjualan dari produk Kampung Batik Laweyan ini dimungkinkan dapat meningkat secara positif.

\section{BAB IV KESIMPULAN DAN SARAN}

Program pengabdian kepada masyarakat dengan tema pengembangan ekspor melalui international e-commerce telah berhasil dilaksanakan di Kampung Batik Laweyan Solo. Program ini dilaksanakan dalam dua sesi utama, yakni penjajagan dan sosialisasi. Sesi penjajagan dilakukan pada bulan Agustus dan September 2018 dengan tujuan mengetahui kondisi nyata dan permasalahan yang dihadapi kelompok sasaran secara lebih mendetail. Dari penjajagan ini, diperoleh gambaran jelas mengenai permasalahan kelompok sasaran/ Berikutnya, sosialisasi dilakukan dengan menyajikan materi sesuai tema dan kebutuhan kelompok sasaran. Adapun sosialisasi dilaksanakan pada tanggal 28 Oktober 2018, melalui metode ceramah dan diskusi aktif.

Implementasi program pengabdian masyarakat yang dilakukan ini masih belum sempurna. Masih ada beberapa kelemahan dan kekurangan yang mungkin butuh perbaikan dan pengembangan. Untuk itu, pelaksana pengabdian menyampaikan saran bagi pengembangan program selanjutnya agar mampu lebih mengakomodasi kepentingan masyarakat dan memaksimalkan manfaat yang didapatkan. Adapun saran tersebut adalah agar program pengabdian ini dapat berlangsung dalam rangka memberikan pembekalan yang lebih dalam mengenai pemasaran internasional melalui e-commerce. Hal ini diharapkan agar para pelaku usaha dapat benar-benar sampai pada implementasi ekspor 
dengan memanfaatkan e-commerce dan memastikan pasarnya dapat terus berkembang secara luas.

\section{DAFTAR PUSTAKA}

BPS. 2011. Statistik Ekspor Jawa Tengah 2011. Jawa Tengah : Badan Pusat Statistik Provinsi Jawa Tengah.

BPS. 2016. Statistik Ekspor Jawa Tengah 2011. Jawa Tengah : Badan Pusat Statistik Provinsi Jawa Tengah.

Cohen, Kim. 2017. Global eCommerce Sales, Trends and Statistics 2016. Dalam https://www.remarkety.com/global-ecommerce-trends-2016, diakses pada 8 Januari 2018.

Sidik, Muhammad. 2017. UMKM Mendorong Ekonomi Kota Solo. Dalam http://koransindo.com/page/news/2017-10-28/0/20/UMKM_Mendorong_Ekonomi_Kota_Solo, diakses pada 11 Januari 2018

Statista. 2018. Retail e-commerce sales worldwide from 2014 to 2021 (in billion U.S. dollars). Dalam https://www.statista.com/statistics/379046/worldwide-retail-e-commerce-sales/ , diakses pada 10 Januari 2018.

Widiastuti, Aris Wasita. 2017. Media Lokal Gandeng UMKM untuk Optimalkan Pasar, dalam https://jateng.antaranews.com/detail/media-lokal-gandeng-umkm-untuk-optimalkanpasar.html, diakses pada 12 Januari 2018. 
LAMPIRAN-LAMPIRAN 